\title{
KURANGNYA KONTROL DIRI SISWA DI LINGKUNGAN SMK NEGERI 2 BATAM
}

\author{
Junierissa Marpaung \\ Dosen Tetap FKIP Prodi Bimbingan Konseling Universitas Riau Kepulauan Batam
}

\begin{abstract}
Abstrak
Berbagai permasalahan yang sering muncul dalam kehidupan ini banyak diakibatkan oleh ketidakmampuan seseorang dalam mengendalikan emosinya. Perkembangan kontrol diri pada dasarnya sejalan dengan bertambahnya usia seseorang. Semakin dewasa diharapkan mempunyai kontrol diri yang lebih baik dibanding saat remaja dan anak-anak. Pengendalian diri sangatlah dibutuhkan oleh siapa saja, karena dengan adanya kontrol diri yang baik memiliki peran dalam menunjukkan siapa diri kita. Kemudian sejauhmana siswa mampu menyesuaikan dirinya di lingkungan sekolah.

Penelitian ini menggunakan metode penelitian kualitatif dengan jenis penelitian kualitatif deskriptif. Penelitian ini mencari, menganalisa gambaran tentang kurangnya control diri siswa di lingkungan SMK Negeri 2 Batam. Sumber Data yang digunakan adalah observasi, wawancara dan dokumentasi. Subjek penelitian ada 1 orang dengan 3 orang sebagai informan penelitian.

Dari hasil penelitian ini ditemukan bahwa penyebab siswa kurang dalam mengontrol dirinya dan dampak yang ditimbulkannya di lingkungan sekolah sehingga siswa tidak efektif dalam menjalani kegiatannya di sekolah karena emosi yang tidak terkontrol.
\end{abstract}

Keyword : kontrol diri, siswa

\section{LATAR BELAKANG MASALAH}

Individu dalam rentang kehidupannya akan selalu berhadapan dengan berbagai masalah. Hanya saja masalah yang dihadapi oleh individu satu akan mempunyai bentuk dan tingkat kesulitan yang berbeda dengan yang lainnya. Tentunya dengan penyelesaian yang berbeda pula. Masalah-masalah yang dihadapi individu sekarang ini begitu kompleks, yang dihadapi manusia dalam waktu yang bersamaan sehingga membutuhkan keterampilan pemecahan masalah yang strategis, yang dilandasi oleh tujuan hidup seseorang dan kontrol diri yang positif. Sebagai salah satu sifat kepribadian kontrol diri pada satu individu dengan individu lain tidaklah sama. Ada yang memiliki kontrol diri yang tinggi dan ada individu yang memiliki kontrol diri yang rendah.

Kontrol diri dapat pula berupa tanggung jawab yang paling besar ketika seseorang berada dalam lingkungan sekolah agar mampu mengendalikan suasana hati karena susasana 
hati bisa sangat berkuasa atas pikiran ingatan dan wawasan. Berdasarkan wawancara dengan Guru BK di SMK Negeri 2 Batam, kurangnya kontrol diri siswa di lingkungan sekolah disebabkan oleh ketidakmampuan siswa dalam mengendalikan emosinya seperti siswa sering sekali menghadapi dan menyelesaikan masalah dengan cara emosi yang meledak-ledak, mudah sensitif dan marah berkepanjangan. Perilaku siswa terlihat dalam kesehariannya disekolah seperti dalam kegiatan belajar maupun bermain siswa sering sekali bertingkah laku tidak menyenangkan yang dapat mengundang temannya menjadi emosi sehingga temannya yang tidak menerima dengan baik akan mudah sekali sensitif dan muncul emosi yang tidak terkontrol tadi.

Adapun hasil wawancara dengan informan pendukung peneliti terkait kurangnya kontrol diri siswa di lingkungan SMK Negeri 2 Batam disebabkan oleh kurangnya siswa dalam mengenali dirinya sendiri, sejauhmana siswa mampu mengendalikan emosinya di lingkungan sekolah baik dalam belajar maupun bermain, seperti dalam belajar dan bermain siswa yang tidak terima dan mudah sensitif akan cepat sekali emosi. Terlihat kurangnya siswa dalam mengenali diri dengan baik sehingga emosi yang keluar tidak mampu dikendalikan dengan baik dan terarah. Adapun observasi di lapangan terdapat siswa yang masih kurang dalam mengontrol dirinya di lingkungan sekolah seperti gambaran pada siswa yang melakukan hal tidak menyenangkan pada temannya misalnya awal mula dari perkataan yang kurang sopan yang mengundang temannya marah lalu tidak terima dengan perkataan tersebut sehingga menjadi emosi yang meledak-ledak dan kurang terkontrol tadi membuat siswa dijauhi dalam belajar maupun bermain.

Berangkat dari permasalahan di atas, peneliti tertarik untuk melakukan penelitian dengan judul "Kurangnya Kontrol Diri Siswa di Lingkungan SMK Negeri 2 Batam”.

\section{RUMUSAN MASALAH}

Rumusan masalah yang ditemukan yaitu gambaran penyebab dan dampak yang ditimbulkan dari kurangnya kontrol diri siswa di lingkungan SMK Negeri 2 Batam?

\section{TUJUAN PENELITIAN}


Untuk melihat gambaran penyebab dan dampak yang ditimbulkan dari kurangnya kontrol diri siswa di lingkungan SMK Negeri 2 Batam.

\section{MANFAAT PENELITIAN}

1. Secara Teoritis

Hasil penelitian ini diharapkan dapat memberikan informasi dan masukan mengenai kontrol diri dalam mentransfer wawasan dan pengetahuan tentang Bimbingan Konseling dalam dunia pendidikan.

2. Secara Praktis

a. Bagi siswa, dengan cara siswa mengenali dirinya dengan baik agar sejauhmana siswa tahu dan mampu dalam mengendalikan emosinya baik dalam kegiatan belajar maupun bermain selama berada di lingkungan sekolah.

b. Bagi guru, sebagai saran dan masukan agar dapat membantu siswa untuk lebih mengontrol dirinya di lingkungan sekolah dengan cara mengenali kontrol diri siswa agar lebih diterima di lingkungan sekolah.

c. Bagi sekolah, sebagai bahan materi untuk menambah ilmu pengetahuan.

d. Bagi peneliti selanjutnya, sebagai bahan masukan untuk menambah pengetahuan dan tambahan referensi buku bacaan.

\section{TINJAUAN PUSTAKA}

\section{Kontrol Diri}

Menurut Surya (dalam Anggia Meytasari, 2013: 23), berpendapat bahwa kontrol diri mempunyai makna sebagai daya yang memberi arah bagi individu dalam hidupnya dan bertanggung jawab terhadap konsekuensi dari perilakunya. Semakin mampu individu mengendalikan perilakunya, maka semakin mungkin menjalani hidupnya secara efektif dan terhindar dari situasi yang dapat mengganggu perjalanan hidupnya. Individu yang kurang 
memiliki kontrol diri disebabkan karena tidak belajar kecakapan dan pengorbanan untuk mencapai satu tujuan dan tidak belajar bagaimana untuk menjadi dirinya sendiri.

Menurut Hurlock (dalam Weny Wijayanti, 2007: 23), terdapat 2 faktor yaitu: (1) Faktor Internal Merupakan faktor yang mempengaruhi kontrol diri seseorang adalah faktor usia dan kematangan. Semakin bertambahnya usia maka akan semakin baik kontrol dirinya. Individu yang matang secara psikologis juga akan mampu mengontrol perilakunya karena telah mampu mempertimbangkan mana hal yang baik dan yang tidak baik bagi dirinya. (2) Faktor Eksternal, Meliputi faktor yang datang dari luar diri seseorang seperti lingkungan keluarga atau teman disekitarnya. Dalam lingkungan keluarga terutama orang tua akan menentukan bagaimana kemampuan kontrol diri seseorang.

\section{METODE PENELITIAN}

Dalam penelitian ini diuraikan tentang lokasi dan waktu penelitian, subjek yang diteliti, teknik pengumpulan data, kredibilitas penelitian dan teknik analisa data. Subjek yang diteliti terdiri dari 1 responden dan 3 informan pendukung. Penentuan subjek dan sumber data dalam penelitian ini sesuai dengan karakteristik responden penelitian yaitu pemilihan responden penelitian berdasarkan pada ciri-ciri tertentu. Dalam penelitian ini akan diambil 1 (dua) orang responden. Adapun ciri -ciri responden tersebut adalah penyebab dan dampak yang ditimbulkan dari kurangnya siswa dalam mengontrol dirinya di lingkungan sekolah.

Teknik pengumpulan data dalam penelitian ini, peneliti menggunakan metode observasi non partisipan. Dimana peneliti tidak terlibat dan hanya sebagai pengamat dalam penelitian mengenai penyebab dan dampak dari kurangnya kontrol diri siswa di lingkungan sekolah. Peneliti juga melakukan wawancara dengan menggunakan wawancara tidak terstruktur dan wawancara semi terstruktur.

Dalam penelitian ini untuk menguji kredibilitas data maka peneliti menggunakan teknik triangulasi sumber. Dimana dalam pengujian kredibilitas ini adalah untuk melakukan pengecekan data dari berbagai sumber dengan berbagai cara dan berbagai waktu, kemudian dideskripsikan, dikategorisasikan mana pandangan yang sama, yang berbeda dan yang spesifik. Maka data yang telah dianalisis oleh peneliti menghasilkan suatu kesimpulan terhadap subjek yang diteliti. Teknik analisa data berupa peneliti melakukan reduksi data, penyajian data dan 
penarikan kesimpulan.

\section{PEMBAHASAN}

Penelitian ini dilakukan untuk mengetahui gambaran penyebab dan dampak yang ditimbulkan dari kurangnya kontrol diri siswa. Gambaran kurangnya kontrol diri siswa terlihat dari: (1) Peningkatan emosional di masa pubertas dimana di masa ini setiap wanita akan mengalaminya, dengan masa ini kita tahu semua pertumbuhan dan perkembangan baik fisik maupun psikis berkembang dengan pesat sehingga menambah kedewasaan seseorang. Bukan hanya itu perkembangan emosional seorang anakpun akan meningkat dan berkembang cepat, sehingga dapat mempengaruhi kontrol diri siswa dalam mengendalikan emosinya. (2) Kurangnya perhatian orang tua. Keluarga merupakan lingkungan utama dimana anak mampu mengutarakan apa yang ingin disampaikannya. Bentuk rasa perhatian yang baik terjalin di dalam keluarga sehingga anak merasa diperhatikan dan di sayang. (3) Beban pelajaran yang semakin tinggi. Pendidikan merupakan usaha sadar dan terencana manusia dalam mentransformasi nilai, informasi dan keterampilan dari satu pihak ke pihak lain. Salah satu yang menentukan berhasil atau tidaknya pendidikan adalah kegigihan siswa dalam menghadapi segala macam bentuk pendidikan. (4) Enggan meminta maaf. Meminta maaf bukanlah hal yang mudah kita utarakan pada seseorang apabila itu tidak benar-benar dari dalam lubuk hati berniat untuk meminta maaf. (5) Kurang menempatkan diri dalam kegiatan belajar maupun bermain. Di lingkungan sekolah tentulah banyak sekali permasalahan yang akan terjadi diantaranya teman yang tidak menyukai kita jika berkelakuan seperti yang tidak diharapkan oleh orang di sekitar kita.

Gambaran Dampak dari Kurangnya Kontrol Diri Siswa yaitu (1) Emosi yang meledakledak. Terbentuknya kontrol diri tidak terlepas dari kesadaran diri yang tinggi atas kemampuan yang dimiliki individu. Kemampuan kontrol diri individu itu ditentukan oleh seberapa besar dan sejauh mana individu tersebut berusaha mempertinggi kontrol dirinya. (2) Kurang mampu mengendalikan diri. Pengendalian diri adalah sebuah sikap kehidupan yang tegas, yang tidak mau dikuasai oleh keinginan-keinginan semata. Karena hal yang terhebat yang dapat dilawan oleh manusia adalah jika mampu memerangi hawa nafsu dan mampu mengendalikan emosi. (3) Penolakan dalam belajar. (4) Penolakan dalam bermain. Kita tidak pernah lepas dari kehidupan 
sosial yang selalu berinteraksi dengan orang lain. Namun, penyesuaian sosial tersebut hendaklah dapat kita jalani dengan layaknya sebagai makhluk sosial yang membutuhkan orang lain.

Tabel. Kemampuan dalam Mengendalikan Diri

\begin{tabular}{|c|c|c|}
\hline Rendah & Sedang & Tinggi \\
\hline $\begin{array}{l}\text { Mudah kehilangan } \\
\text { mudah frustrasi, } \\
\text { meluapkan ekspresi emosi } \\
\text { secara meledak-ledak atau } \\
\text { tidak efektif dalam } \\
\text { menjalankan aktivitas karena } \\
\text { emosi yang tidak terkontrol. }\end{array}$ & $\begin{array}{l}\text { Telah sanggup memberikan } \\
\text { respon dengan tenang dan } \\
\text { mendiskusikannya secara adil. }\end{array}$ & $\begin{array}{lr}\text { Bisa memberikan respon } \\
\text { secara konstruktif, } & \text { bias } \\
\text { membangun hubungan yang } \\
\text { lebih positif } & \text { dan } \\
\text { mengantisipasi masalah. } & \end{array}$ \\
\hline Tidak tahan terhadap tekanan. & \begin{tabular}{lr}
\multicolumn{2}{l}{ Sudah bisa mengelola tekanan } \\
secara efektif, tidak \\
mempengaruhi & hasil \\
pekerjaan atau & tidak \\
mempengaruhi & proses \\
pekerjaan. &
\end{tabular} & $\begin{array}{l}\text { Telah mampu menenangkan } \\
\text { diri anda dan orang lain atau } \\
\text { sanggup memainkan peranan } \\
\text { sebagai pemimpin. }\end{array}$ \\
\hline $\begin{array}{l}\text { Telah dapat mengontrol emosi } \\
\text { tetapi belum } \\
\text { menggunakannya } \\
\text { konstruktif. }\end{array}$ & & \\
\hline
\end{tabular}

\section{KESIMPULAN}

Berdasarkan hasil penelitian dan pembahasan tentang Kurangnya Kontrol Diri Siswa di Lingkungan SMK Negeri 2 Batam, maka dapat diambil kesimpulan: Peningkatan emosional di masa pubertas disebabkan karena kurangnya perhatian orang tua, beban pelajaran yang semakin tinggi, enggan meminta maaf dan kurang menempatkan diri dalam belajar dan bermain. Sedangkan dampak yang akan ditimbulkan dari kurangnya kontrol diri siswa adalah : emosi yang meledak-ledak, kurang mampu mengendalikan diri, penolakan dalam belajar dan penolakan dalam bermain.

\section{Chart atau Bagan Penelitian}

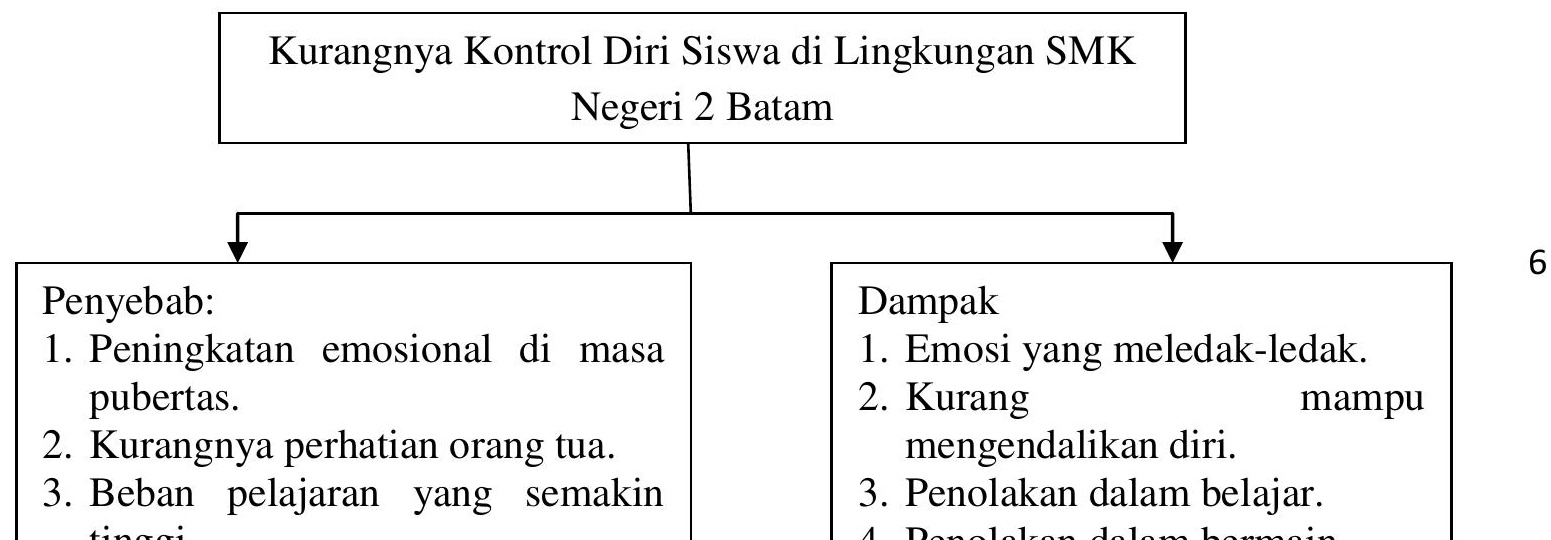




\section{DAFTAR PUSTAKA}

Anggia Meytasari. (2013). Kontribusi Kontrol Diri terhadap Kedisiplinan Siswa di Sekolah dan Implikasinya bagi Program BK. Skripsi (Tidak diterbitkan). Bandung: Universitas Pendidikan Indonesia.

Djam'an Satori. (2012). Metodologi Penelitian Kualitatif. Bandung: Alfabeta.

Nitha Luthfia. (2007). Hubungan Kontrol Diri dengan Motivasi Berprestasi Siswa SMAN 1 Sutojayan. Skripsi (Tidak diterbitkan). Malang: Fakultas Psikologi Universitas Islam Negeri Malang.

Poerwandari. (2007). Pendekatan Kualitatif untuk Penelitian Perilaku Manusia. Jakarta. Perfecta.

Sugiyono. (2013). Metode Penelitian Kuantitatif, Kualitatif dan R\&D. Bandung: Alfabeta.

Sofia Ratnawati, dkk. (1998). Efektivitas Pelatihan Kontrol Diri terhadap Peningkatan Penerimaan Diri dan Harga diri. Jurnal Psikologi. 1998.

Yuniar Rachdianti. (2011). Hubungan antara Self Control dengan Intensitas Penggunaan Internet Remaja. Skripsi (Tidak diterbitkan). Jakarta: Fakultas Psikologi Universitas Islam Negeri Syarif Hidayatullah.

Ratna Wahyuningsih. (2008). Hubungan antara Konsep Diri dan Kontrol Diri dengan Perilaku Seksual Pranikah pada Siswa Kelas XI SMA Negeri 1 Malang. Skripsi (Tidak diterbitkan). Malang: Fakultas Psikologi Universitas Islam Negeri.

Liliyana Sari. (2013). Pengaruh Kontrol Diri terhadap Perilaku Cyberloafing pada Pegawai perpustakaan. Skripsi (Tidak diterbitkan). Medan: Fakultas Psikologi Universitas Sumatera Utara. 